Jurnal Pemberdayaan: Publikasi Hasil Pengabdian kepada Masyarakat

Vol. 3, No. 2, Agustus 2019, Hal. 241-244

ISSN: 2580-2569; e-ISSN: 2656-0542

DOI: https://doi.org/10.12928/jp.v3i2.849

\title{
Penyuluhan demam berdarah dengue (DBD) dan tanaman pengusir nyamuk di Desa Modalan, Banguntapan
}

\author{
Hery Setiyawan, Asih Sri Lestari, Elly Nur Ayuningtyas, Annisa Meradji, Elly Diana, \\ Evi Budi Utami \\ Politeknik Kesehatan Bhakti Setya Indonesia, Bantul, DIY \\ asihs.lestari@gmail.com
}

\begin{abstract}
ABSTRAK
Peningkatan jumlah penduduk Indonesia menyebabkan kebutuhan papan juga meningkat. Semakin lama bangunan dan perumahan juga semakin padat dan menyebabkan meningkatnya populasi nyamuk di sekitar rumah. Nyamuk tidak hanya hidup di lingkungan air kotor saja, akan tetapi pada air bersih juga. Masyarakat umumnya sudah menggunakan obat nyamuk berbahan kimia, namun belum banyak yang mengetahui bahaya dari efek yang ditimbulkan. Cara untuk menghindari bahaya dari efek obat nyamuk berbahan kimia yaitu dengan menggunakan tanaman pengusir nyamuk. Salah satu upaya yang dapat dilakukan yaitu dengan memberikan pengetahuan kepada masyarakat untuk memanfaatkan tanaman sebagai pengusir nyamuk. Tujuan dari kegiatan ini untuk menambah pengetahuan tentang bahaya nyamuk demam berdarah serta cara menanggulanginya dengan cara organik. Kegiatan ini dilakukan di lingkungan desa Modalan, Banguntapan dengan tahapan persiapan pada tanggal 20 April 2019, sedangkan pelaksanaan penyuluhan pada tanggal 21 April 2019. Materi yang diberikan tentang penyakit DBD dan tanaman pengusir nyamuk. Hasil dari kegiatan ini adalah menambah pengetahuan masyarakat tentang bahaya demam berdarah dan manfaat tanaman pengusir nyamuk.
\end{abstract}

Kata Kunci: DBD, Bahaya Obat Nyamuk, Tanaman Pengusir Nyamuk, Mondalan

\begin{abstract}
The increasing number of Indonesians causes the demand for boards to increase. The longer buildings and housing are also getting denser and cause an increase in the mosquito population around the house. Mosquitoes do not only live in dirty water environments, but also in clean water. People generally use chemical insect repellents, but not many know the dangers of the effects. Ways to avoid the dangers of the effects of insect repellents made from chemicals, namely by using mosquito repellent plants. One effort that can be done is to provide knowledge to the community to use plants as mosquito repellents. The purpose of this activity is to increase knowledge about the dangers of dengue fever mosquitoes and how to overcome them by organic means. This activity was carried out by counseling at RT 01 Modalan, Banguntapan on April 21, 2019. The material was given about dengue disease and mosquito repellent plants. Counseling is conducted $1 x$ with an allocation of 45 minutes. The conclusion of this activity is to educate the public about the dangers of dengue and the benefits of mosquito repellent plants.
\end{abstract}

Keywords: DHF, Danger of Mosquito Repellent, Mosquito Repellent Plant, Mondalan

\section{PENDAHULUAN}

Penyakit DBD adalah penyakit infeksi oleh virus Dengue yang ditularkan melalui gigitan nyamuk Aedes, dengan ciri demam tinggi mendadak disertai manifestasi perdarahan dan bertendensi menimbulkan renjatan (shock) dan kematian. Sampai sekarang penyakit DBD belum ditemukan obat maupun vaksinnya, sehingga satu-satunya cara untuk mencegah terjadinya penyakit ini dengan memutuskan rantai penularan yaitu dengan pengendalian vektor.

Vektor utama penyakit DBD di Indonesia adalah nyamuk Aedes aegypti. Tempat yang disukai sebagai tempat perindukannya adalah genangan air yang terdapat dalam wadah 
(kontainer) tempat penampungan air artifisial misalnya drum, bak mandi, gentong, ember, dan sebagainya; tempat penampungan air alamiah misalnya lubang pohon, daun pisang, pelepah daun ke ladi, lubang batu; ataupun bukan tempat penampungan air misalnya vas bunga, ban bekas, botol bekas, tempat minum burung dan sebagainya. Hasil survei Departemen Kesehatan RI di 9 kota besar di Indonesia pada tahun 1986-1987 menunjukkan bahwa satu diantara tiga rumah maupun tempat umum ditempati jentik nyamuk Aedes. Disamping itu, pengetahuan, sikap, dan perilaku masyarakat tentang pencegahan penyakit DBD pada umumnya sangat kurang.

Masyarakat pada umumnya lebih sering menggunakan obat pengusir nyamuk berbahan kimia. Namun sebenarnya memakai obat pengusir nyamuk berbahan kimia sangat berbahaya bagi kesehatan manusia. Wilayah Indonesia banyak memiliki tanaman berkhasiat obat, pengusir serangga, dan tanaman produktif lainnya. Tanaman penghasil (bahan) anti nyamuk adalah istilah untuk tanaman yang seluruh atau sebagian bagian tanamannya dapat dimanfaatkan atau diolah untuk menghasilkan bahan pengusir nyamuk. Tanaman tersebut, ada yang dapat digunakan secara langsung, misalnya dengan hanya meremas remas daun atau bunganya yang kemudian dioleskan ke kulit agar terhindar dari gigitan nyamuk. Sebagian yang lain, ada tanaman yang harus melalui proses lebih rumit yakni destilasi. Destilasi merupakan proses penyulingan agar dapat menghasilkan minyak yang dikenal sebagai minyak atsiri. Minyak atsiri inilah yang nantinya digunakan secara tunggal atau sebagai campuran pada repellent nyamuk (Yanuar dan Arda, 2007).

Pedukuhan Modalan merupakan daerah yang terkena penyakit DBD pada tahun 2018 karena faktor kurangnya pengetahuan masyarakat tentang tanaman pengusir nyamuk seperti lavender (Lavandula agustifolia) dan kurangnya kesadaran masyarakat akan pentingnya kebersihan lingkungan. Oleh karena itu, tim dari Poltekkes BSI melakukan kegiatan penyuluhan berupa sosialisasi penyakit demam berdarah serta cara menanggulanginya. Perlu dipahami, penyuluhan bukanlah semata -mata sebagai forum penyampaian hal-hal yang boleh atau tidak boleh dilakukan masyarakat. Sebaiknya masyarakat dibekali pengetahuan dan ketrampilan tentang cara-cara pengendalian vektor yang memungkinkan mereka menentukan pilihan terbaik segala hal yang berkaitan dengan masalah kesehatan secara individu maupun secara kolektif . Diharapkan setelah adanya kegiatan ini, masyarakat Modalan, Banguntapan dapat lebih memperhatikan lingkungan agar dapat mencegah terjadinya penyebaran nyamuk demam berdarah di masa yang akan datang. Diharapkan juga lingkungan menjadi lebih hijau (Eco Green).

\section{METODE}

Metode yang digunakan berupa penyuluhan tentang bahaya demam berdarah serta pengenalan tanaman pengusir nyamuk yang dilaksanakan di salah satu rumah warga. Mahasiswa yang terlibat dalam penyuluhan ada 5 orang beserta 1 dosen. Persiapan dan pelaksanaan penyuluhan dilakukan di lingkungan padukuhan Modalan Banguntapan Bantul pada 20 dan 21 April 2019. Penyuluhan diikuti oleh 25 orang anggota PKK Desa Modalan Banguntapan Bantul.

\section{HASIL, PEMBAHASAN DAN DAMPAK}

Kegiatan dilaksanakan dengan metode penyuluhan kepada ibu - ibu PKK Dusun Modalan, Jaranan, Banguntapan, Bantul, Yogyakarta. Kegiatan ini disambut baik oleh ibu PKK karena menambah wawasan pengetahuan mereka. Gambaran kegiatan tersaji pada Gambar 1, 2, dan 3. Lingkungan yang bersih akan mampu menekan laju pertumbuhan dan perkembangan nyamuk Aedes aegypti dan Aedes albopictus selaku vektor DBD (Rahayu \& Ustiawan, 2013; Fadilla dkk., 2015; Hendri dkk., 2015). Selain itu, perilaku pencegahan dengan 3M dapat mengurangi keberhasilan larva nyamuk untuk menjadi nyamuk dewasa (Husna dkk., 2016; 
Ernawati dkk., 2018). Masa perkembangan larva nyamuk Aedes aegypti dan Aedes albopictus tergolong singkat, yaitu kurang lebih 8-12 hari (Boesri, 2011; Jacob dkk., 2014). Masa perkembangan yang singkat ini tentunya dapat diputuskan atau dihambat dengan cara melaksanakan 3M dan pemantauan jentik secara teratur (Husna dkk., 2016; Ernawati dkk., 2018).

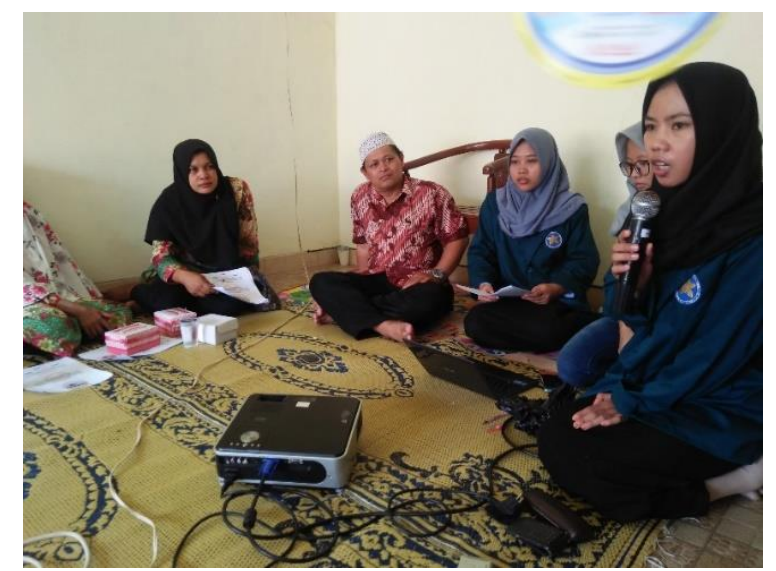

Gambar 1. Pemateri menyampaikan penyuluhan

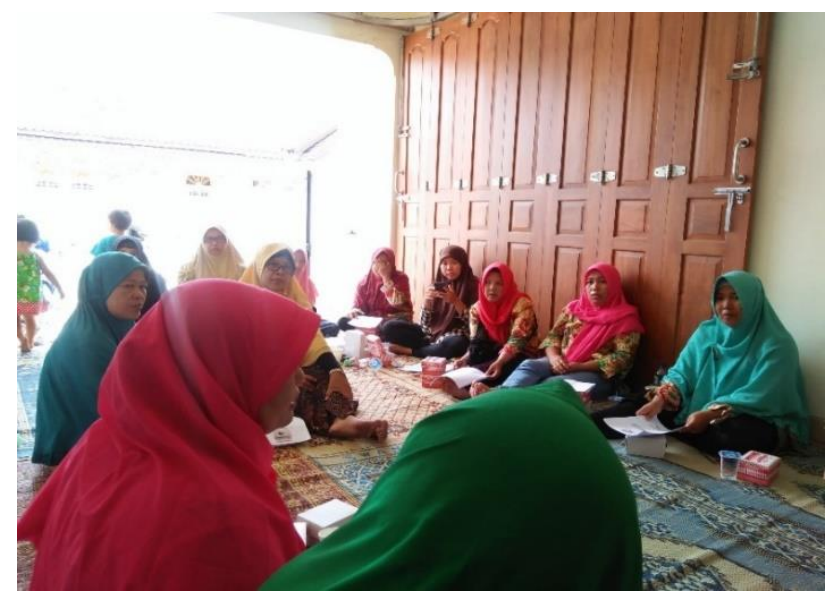

Gambar 2. Kegiatan diikuti oleh ibu - ibu PKK Modalan, Banguntapan

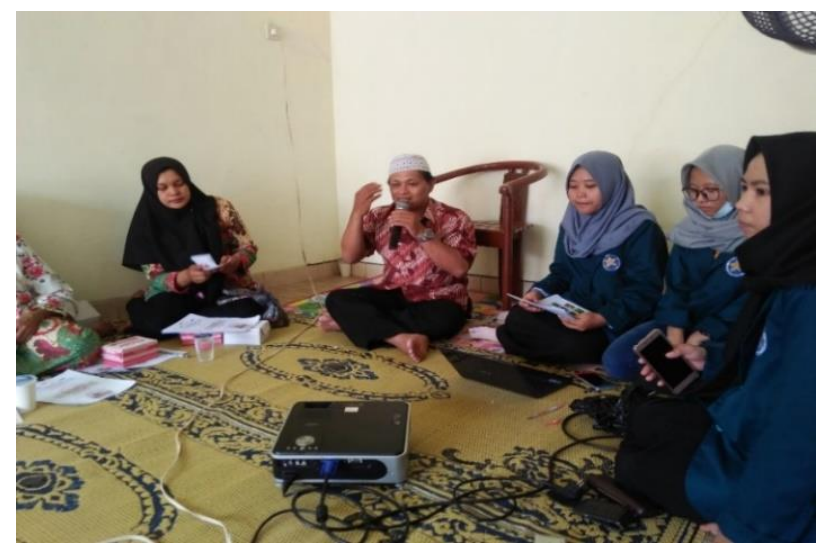

Gambar 3. Tanya jawab setelah presentasi materi

Selanjutnya pemateri menjelaskan jenis-jenis tanaman yang dapat dimanfaatkan sebagai tanaman pengusir nyamuk. Beberapa jenis tanaman yang dapat dikelompokkan sebagai tanaman pengusir nyamuk diantaranya Zodia (Evodia suaveolens), Serai (Andropogon nardus L.), Lavender (Lavandula angustifolia), geranium (Pelargonium citrosa), Rosemary. Tanaman 
tanaman ini terbukti mengandung zat aktif yang dihindari oleh nyamuk. Contohnya seperti linalyl acetate dan linalool7 $\left(\mathrm{C}_{10} \mathrm{H}_{18} \mathrm{O}\right)$. Penyampaian materi dilakukan secara langsung dengan metoda ceramah yang didukung dengan brosur yang dibagikan kepada peserta. Diharapkan dengan metode tersebut, dapat memudahkan peserta untuk memahami materi yang disampaikan.

Dampak yang diberikan dari kegiatan ini adalah adanya tambahan pengetahuan kepada ibu-ibu PKK tentang bahaya nyamuk demam berdarah beserta tanaman pengusir nyamuk. Sebelum adanya kegiatan ini, belum ada penyampaian materi tentang cara pencegahan nyamuk demam berdarah menggunakan tanaman pengusir nyamuk karena kebanyakan masyarakat masih menggunakan obat nyamuk berbahan kimia. Secara umum kegiatan pengabdian masyarakat yang diadakan terlaksana dengan baik dan lancar. Diharapkan peserta dapat membudidayakan tanaman pengusir nyamuk setelah mendapatkan pengetahuan besarnya manfaat tanaman tersebut. Pembudidayan tanaman pengusir nyamuk disamping mengusir nyamuk juga dapat membuat lingkungan menjadi hijau dan sehat.

\section{SIMPULAN}

Kesimpulan dari kegiatan ini adalah pentingnya memiliki pengetahuan yang cukup tentang nyamuk demam berdarah dan cara pencegahannya termasuk dengan menggunakan tanaman pengusir nyamuk. Tanaman pengusir nyamuk juga dapat digunakan sebagai fungsi lain yaitu sebagai penghijauan daerah sekitar. Dampak positif yang diberikan dari kegiatan ini adalah meningkatnya pengetahuan masyarakat untuk mencegah penyebaran nyamuk demam berdarah di masa yang akan mendatang.

\section{DAFTAR PUSTAKA}

Boesri, H. (2011), Biologi dan peranan Aedes albopictus (Skuse) 1984 sebagai penular penyakit, Aspirator, 3(2): 117-125.

Ernawati, Bratajaya, C. N., \& Martina, S. E. (2018), Gambaran praktik pencegahan Demam Berdarah Dengue (DBD) di wilayah endemik DBD, e-jurnal UMM, 9(1): 17-24.

Fadilla, Z., Hadi, U. K., \& Setiyaningsih, S. (2015), Bioekologi vektor demam berdarah dengue (DBD) serta deteksi virus dengue pada Aedes aegypti (Linnaeus) dan Ae. albopictus (Skuse) (Diptera: Culicidae) di kelurahan endemic DBD Bantarjati, Kota Bogor, Jurnal Entomologi Indonesia, 12(1): 31-38.

Hendri, J., Santya, R. N. R. E., \& Prasetyowati, H. (2015). Distribusi dan kepadatan vektor demam berdarah dengue (DBD) berdasarkan ketinggian tempat di Kabupaten CiamisJawa Barat, Jurnal Ekologi Kesehatan, 14(1): 17-28.

Husna, R. N., Wahyuningsih, N. E., \& Dharminto. (2016), Hubungan perilaku 3M plus dengan kejadian demam berdarah dengue (DBD) di Kota Semarang (Studi di Kota Semarang wilayah atas), Jurnal Kesehatan Masyarakat, 4(5): 170-177.

Jacob, A., Pijoh, V. D., \& Wahongan, G. J. P. (2014), Ketahanan hidup dan pertumbuhan nyamuk Aedes spp pada berbagai jenis air perindukan, Jurnal e-Biomedik, 2(3): 1-5.

Rahayu DF, Ustiawan A. (2013). Identifikasi Aedes aegypti dan Aedes albopictus. J of Balaba. 9(1):7-10.

Yanuar, Firda., Arda dinata. (2007). Kenali tanaman pengusir nyamuk. Jurnal alternatif. Volume 2 No 2. 